\title{
CHARACTERIZING A TROPICAL SOIL VIA SEISMIC IN SITU TESTS
}

\author{
Breno Padovezi Rocha ${ }^{1,2}$ and Heraldo Luiz Giacheti ${ }^{2}$
}

\begin{abstract}
The shear wave velocity $\left(V_{s}\right)$ is an important geotechnical parameter to be used in dynamic problems (e.g. earthquakes and vibration problems) as well as in static deformation analysis such as excavations and foundation engineering design. There are several in situ seismic tests to determine $V_{s}$ such as the crosshole and the downhole techniques, as well as hybrid tests (e.g. seismic dilatometer - SDMT). This paper presents crosshole, downhole and SDMT tests carried out in a typical tropical soil profile from Brazil. Advantages and limitations regarding the test procedures and interpretation are briefly presented and differences observed among $V_{S}$ determined by these techniques are discussed. Shear wave velocities $\left(V_{S}\right)$ estimated from the crosshole, downhole and SDMT tests ranging from 194 to 370 $\mathrm{m} / \mathrm{s}$. The shear wave velocity suggests that the experimental site could be divided into two strata, which are in agreement with soil profile description. The maximum shear modulus $\left(G_{0}\right)$ calculated from the $V_{s}$ by theory of elasticity can be used to show the investigated tropical soil is a typical unusual geomaterial. This article also emphasizes that the SDMT is a useful test for site investigation since it allows a great means for profiling geostratigraphy and soil engineering properties during routine site investigation as well as for statics and dynamics problems.
\end{abstract}

Keywords: shear wave velocity, maximum shear modulus, crosshole, downhole, SDMT.

RESUMO. A velocidade de onda cisalhante $\left(V_{S}\right)$ é um parâmetro geotécnico empregado em análises dinâmicas (terremotos e problemas de vibração), bem como em análises estáticas (escavações e projeto de fundações). Existem vários ensaios sísmicos de campo para a determinação de $V_{s}$, entre eles as técnicas crosshole e downhole, e os ensaios híbridos (por exemplo, dilatômetro sísmico - SDMT). Este artigo apresenta os ensaios crosshole, downhole e SDMT realizados em um perfil típico de solo tropical do Brasil, as vantagens e limitações dos procedimentos de ensaio e de interpretação são brevemente apresentadas, e as diferenças observadas entre os valores de $V_{S}$ determinados pelas diferentes técnicas são discutidas. Os perfis de $V_{S}$ determinados pelas técnicas variaram de 194 a $370 \mathrm{~m} / \mathrm{s}$. A velocidade da onda cisalhante sugere que o campo experimental investigado pode ser dividido em dois horizontes, os quais estão de acordo com a descrição do perfil do solo estudado. 0 módulo de cisalhamento máximo $\left(G_{0}\right)$, calculado a partir de $V_{S}$ pela teoria da elasticidade, pode ser utilizado para demonstrar 0 comportamento não convencional do solo investigado. Este artigo também enfatiza que o SDMT é um ensaio geotécnico útil para a investigação geotécnica do subsolo, uma vez que permite a definição do perfil estratigráfico e a estimativa de parâmetros estáticos e dinâmicos de um projeto.

Palavras-chave: velocidade de onda cisalhante, módulo de cisalhamento máximo, crosshole, downhole, SDMT.

\footnotetext{
${ }^{1}$ Universidade de São Paulo, Departamento de Geotecnia, Avenida Trabalhador São-Carlense, 400, Pq Arnold Schimidt, 13566-590, São Carlos, SP, Brazil - E-mail: brenop@sc.usp.br

${ }^{2}$ Universidade Estadual Paulista, Departamento de Engenharia Civil e Ambiental, Avenida Eng. Luiz Edmundo C. Coube, 14-01, Vargem Limpa, 17033-360, Bauru, SP, Brazil -E-mail: h.giacheti@unesp.br
} 


\section{INTRODUCTION}

The shear wave velocity $\left(V_{s}\right)$ profile is of important use in geotechnical engineering. During an earthquake, the ground motion of the site is significantly affected by the local site condition, and the average $V_{s}$ is the key variable for site characterization in geotechnical earthquake engineering (Sully \& Campanella, 1995; UBC, 1997; Bang \& Kim, 2007). The $V_{s}$ values can be used for a static deformation analysis such as slope stability and the settlement and an evaluation for ground improvements (Burland et al., 1977; Kim \& Park, 1999; Ashford \& Sitar, 2002). Recently, maximum shear modulus $\left(G_{0}\right)$ calculated from $V_{s}$ profiles has also been used to investigate non-textbook materials (Robertson, 2016; Marchetti \& Monaco, 2018). For these reasons, the demand for a site investigation for $V_{s}$ and $G_{0}$ profiling is increasing rapidly in the field of geotechnical engineering.

Several field seismic tests such as the crosshole, downhole, multi-channel analysis of surface waves (MASW) as well as hybrid tests (e.g. seismic cone and seismic dilatometer) are generally used for an evaluation of the $V_{s}$ profile (Hunter et al., 2002; Stokoe et al., 2004). Each test has its own advantages and limitations and the results may not be coincident in many cases due to scale problems and the difference among the tests. Therefore, it is important to select an adequate field testing technique that considers the site conditions and the importance of the projects for obtaining a reliable $V_{s}$ profile (Bang \& Kim, 2007).

A large portion of Brazil's territory is covered with tropical soils, however, the geotechnical literature about dynamic parameters of these soils is very limited since dynamic tests are not currently carried out in Brazil. The term tropical soil includes both lateritic and saprolitic soils. Saprolitic soils are residual and retain the macro fabric of the parent rock. Lateritic soils can be either residual or transported and are distinguished by the occurrence of the laterization process, which is an enriching of a soil with iron and aluminum and their associated oxides, caused by weathering in regions which are hot, acidic, and at least seasonally humid (Nogami \& Villibor, 1981). Following laterization, high concentration of oxides and hydroxides of iron and aluminum bonds support a highly porous structure. The contribution of this microstructure (cementation) to the soil stiffness depends on the strain level the soil will experience. These characteristics increase the preconsolidation stress and cohesion intercept (Vaughan et al., 1988) and the most existing empirical correlation should be employed with caution (Robertson, 2016).

This paper presents crosshole, downhole, and seismic dilatometer (SDMT) tests carried out in a tropical soil site located at the Universidade de São Paulo, in São Carlos, Brazil. Advantages and limitations regarding the test procedures and interpretation are briefly discussed, and the differences observed between $V_{s}$ and $G_{0}$ profiles determined by these techniques are also discussed. This paper also discusses the use of the $G_{0} / E_{D}$ and $G_{0} / M_{D M T}$ ratio as a useful index for site characterization of tropical soils.

\section{IN SITU SEISMIC TESTS}

\section{Crosshole tests}

The crosshole seismic test is one of the most effective techniques for the in situ determination of $V_{s}$. The main objective of this technique is determining the compression $(\mathrm{P})$ and/or shear $(\mathrm{S})$ propagation velocities along depth, being regulated by ASTM (2007).

The test consists of generating seismic waves in a borehole and registering their arrivals in one or more adjacent boreholes. The spacing between the source borehole and the first receiver borehole has to be around 1.5 to $3.0 \mathrm{~m}$ and the distance between subsequent receiver boreholes has to be 3.0 to $6.0 \mathrm{~m}$ apart. Spacing between the source borehole and the receiver borehole have to be 1.5 to $5.0 \mathrm{~m}$ for two boreholes (ASTM, 2007). The source and the seismic receivers (geophones or accelerometers) are positioned at the same depth, and the $V_{s}$ is typically determined every meter depth interval. Figure 1 shows a sketch of the crosshole seismic test.

The interpretation of crosshole test data for determining $V_{s}$ basically consists of identifying the first-arrival time of S-wave from the seismograms. S-waves are characterized by an increase in the amplitude of the signal as well as by the fact that it polarizes: inverting the direction of the blow, all phases corresponding to the shear waves appear inverted. In addition to the increase in the amplitude and its polarization, the S-wave can also be identified when the signal frequency decreases.

Special attention should be given in opening and preparing the source and the receiver boreholes. The procedure suggested by ASTM (2007), consists of coating them with metallic or PVC (polyvinyl chloride) pipes and grouting the borehole by a small diameter grout tube insert to the bottom of the borehole, by means of using a cement mix. 


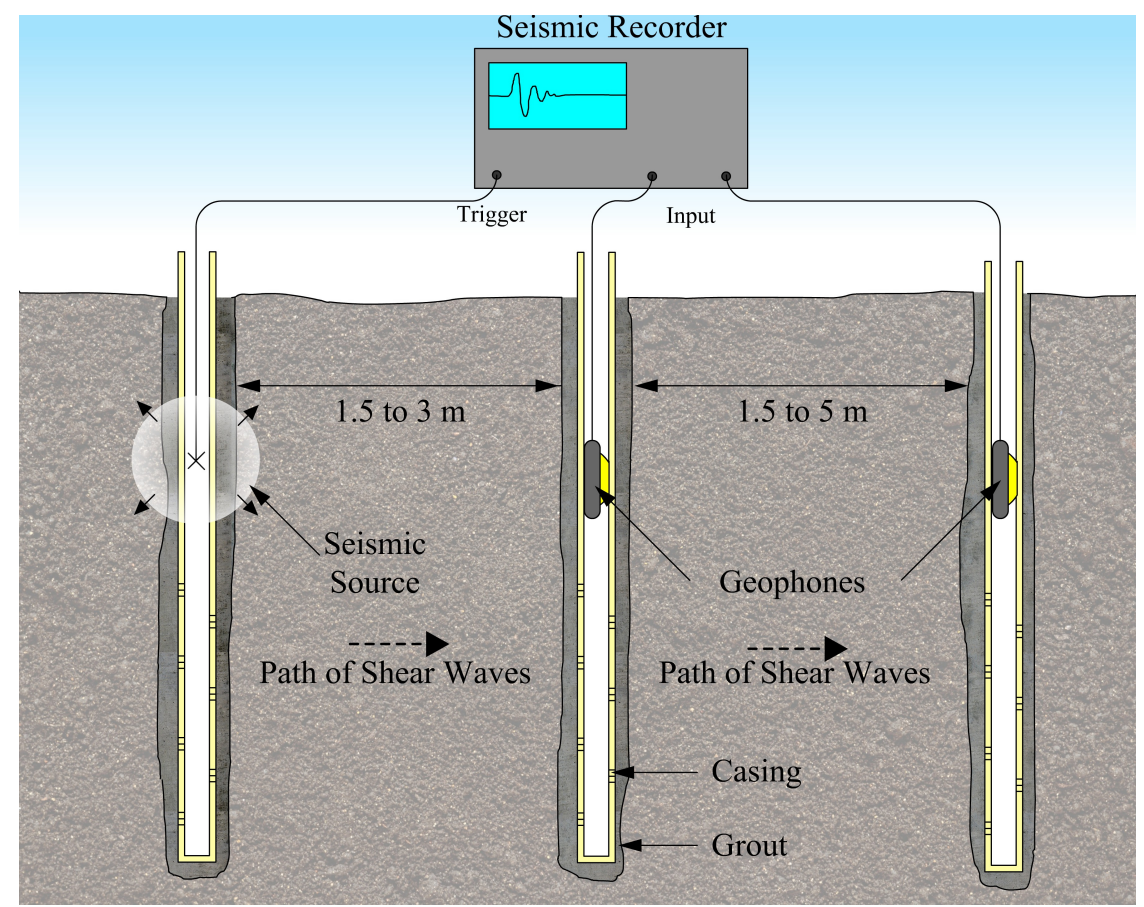

Figure 1 - Sketch of the crosshole seismic test (adapted from ASTM, 2007).

\section{Downhole tests}

The downhole seismic test (ASTM, 2008) is carried out using a single borehole. This test is performed inserting a seismic probe in a prepared borehole or into the soil mass and, in this case, there is no need for preparing the borehole. Figure 2 shows a sketch of the downhole seismic test.

The test consists in determining the arrival time of seismic waves generated on the ground surface and travelling down to an array of vertically installed seismic sensors positioned at different depths. The interpretation of the test data considers that the travel path between the source and the receiver follows a linear trajectory. In heterogeneous materials, this path is not a straight line and Snell's law of refraction can to be used.

The determination of shear wave propagation velocity can be done by three different methods: first arrival, cross-over and cross-correlation. According to Campanella \& Stewart (1992), the cross-correlation method surpasses the others because it is less affected by signal distortions, leading to more consistent and reliable results.

\section{Seismic Dilatometer Test (SDMT)}

The dilatometer test (DMT) consists of a stainless-steel blade with a thin flat circular expandable membrane on one site. Gas pressure is applied through the control unit, inflating the membrane every $0.2 \mathrm{~m}$ depth intervals. The intermediate DMT parameters (Material Index $-I_{D}$, Horizontal Stress Index $-K_{D}$ and Dilatometer Modulus $-E_{D}$ ) are calculated from $p_{0}$ (corrected first reading) and $p_{1}$ (corrected second reading) and are used to soil classification and estimative of geotechnical parameters (Marchetti 1980; Marchetti et al., 2001).

The seismic dilatometer (SDMT) is the combination of the standard DMT equipment with a seismic module for measuring the shear wave velocity $V_{s}$ (Hepton, 1988; Martin \& Mayne, 1997, 1998; Mayne et al., 1999; Marchetti et al., 2008). The test is conceptually equivalent to the seismic cone (SCPT). The seismic module is a cylindrical element placed above the DMT blade, equipped with two receivers, spaced $0.5 \mathrm{~m}$ apart (Fig. 3a). $V_{s}$ is calculated (Fig. 3b) by the ratio between the difference in distance from the source and the two receivers $\left(S_{2}-S_{1}\right)$ and the delay of the arrival of the impulse from the first to the second receiver $(\Delta t)$. Figure $3 \mathrm{c}$ shows the seismic dilatometer equipment.

The signal is amplified and digitized at depth. The true interval test configuration with two receivers avoids possible inaccuracy in the determination of the "zero time" at the hammer impact, sometimes observed in the pseudo-interval one-receiver configuration (Marchetti et al., 2008). In addition to $V_{s}$ and $G_{0}$ profiles determination, SDMT allows estimating the $\mathrm{G}-\gamma$ decay curves and assessing the presence of microstructure (e.g. 


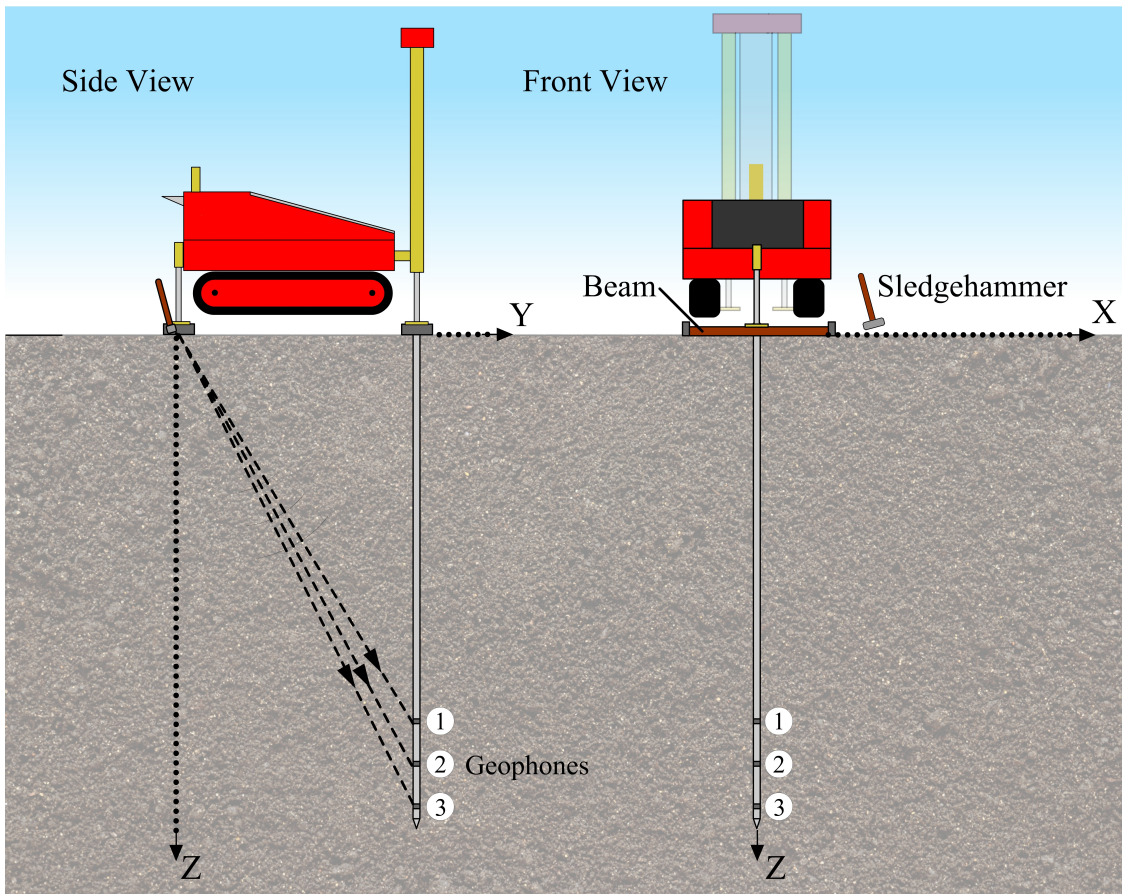

Figure 2 - Side and front view of the downhole test with three geophones seismic probe (adapted from Karl et al., 2006).
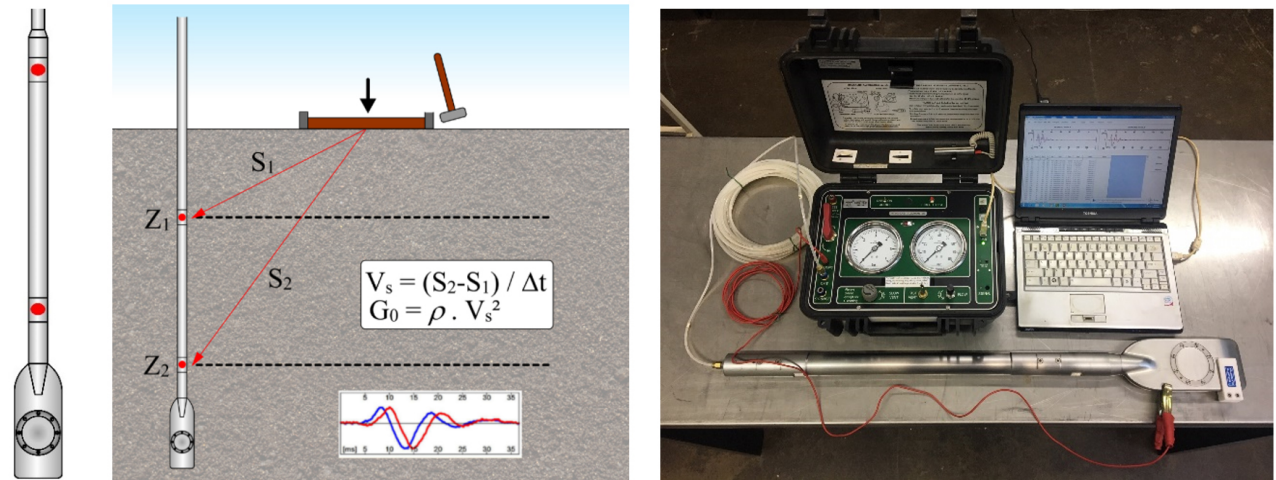

Figure 3 - Seismic Dilatometer (SDMT): (a) DMT blade with seismic module; (b) Schematic representation of the SDMT; (c) Seismic dilatometer equipment (adapted from Marchetti et al., 2008).

bonding and cementation) (Ashford \& Sitar, 2002; Marchetti \& Monaco, 2018).

\section{MAXIMUM SHEAR MODULUS $\left(G_{0}\right), G_{0} / E_{D}$ AND $G_{0} / M_{D M T}$ RATIO}

$G_{0}$ is the stiffening parameter that refers to the initial undisturbed state of the soil and allows assessing the stress-strain-strength response of soils for static, cyclic and dynamic loads, both for drained and undrained conditions (Wang et al., 2018). It is largest at very low strains and decreases with increasing shear strain.
It has been found that the initial maximum shear modulus is constant for strains less than $10^{-4} \%$ (Sully \& Campanella, 1995) although this may vary with plasticity index (PI) (Vucetic \& Dobry, 1991). It can be calculated from shear wave velocity $\left(V_{s}\right)$ by in situ or laboratory tests by the Equation 1 (Woods, 1978):

$$
G_{o}=\rho \cdot\left(V_{s}\right)^{2}
$$

where $\rho=\gamma / g$ total mass density, $\gamma=$ soil unit weight, and $g=$ gravitational constant. 


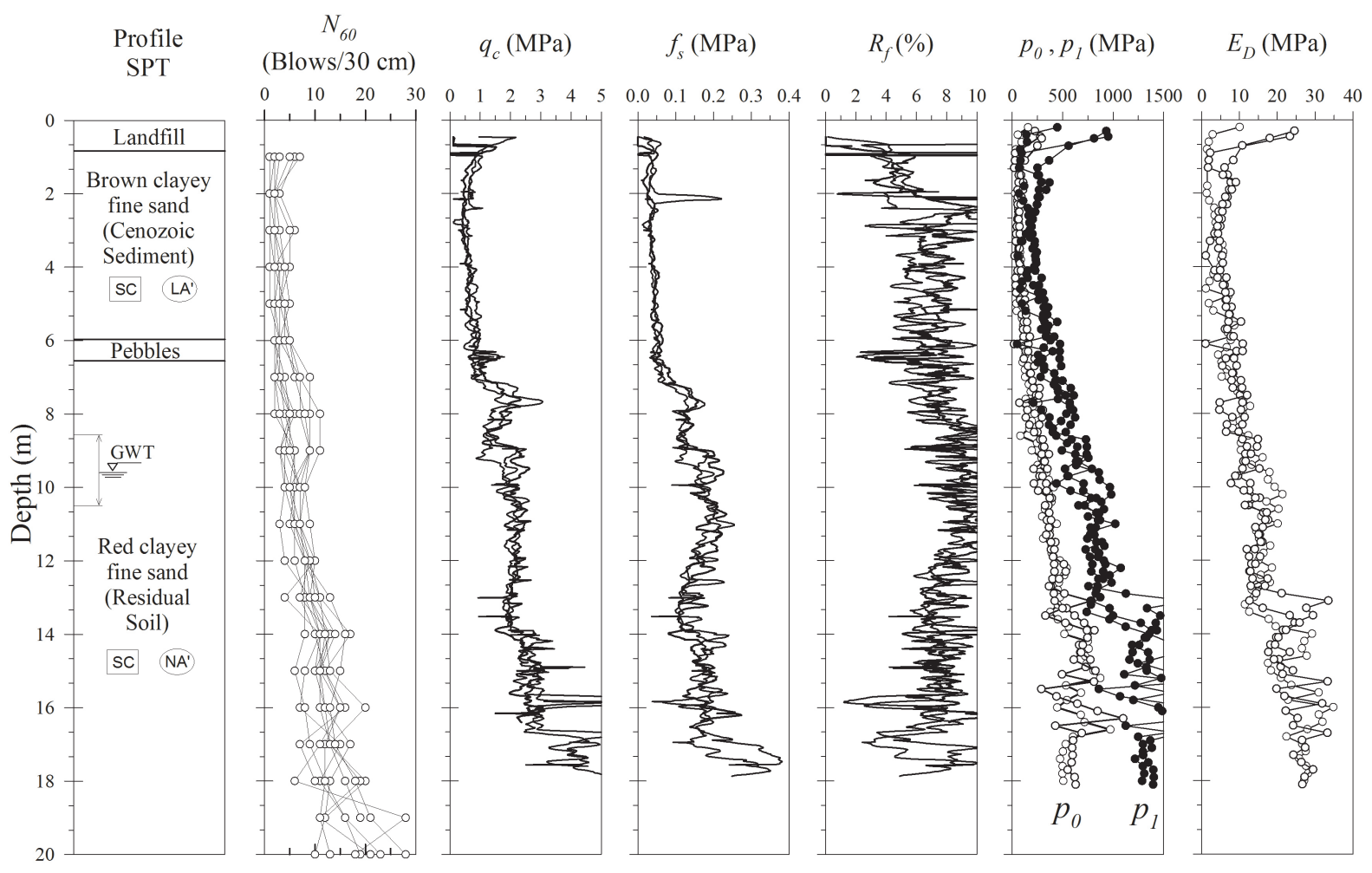

Figure 4 - Synthesis of in situ tests for the study area (adapted from Giacheti et al., 2006a and Rocha, 2018).

Microstructure (e.g. bonding and cementation) improves the mechanical behavior of the soil, however, quantify this effect is not easy (Baligh \& Scott, 1975; Robertson, 2016). Penetration probes insertion may partly destroy the microstructure. In general, it can be expected that the DMT insertion may produce pronounced destructive effects in cemented soils (Baligh \& Scott, 1975; Marchetti \& Panone, 1981; Marchetti \& Monaco, 2018).

If SDMT is carried out, $G_{0}$ can be calculated from $V_{s}$ (Eq. 1) and additional information on microstructure can be obtained using the method illustrated by Cruz et al. (2012). These authors have demonstrated the possibility of combining $E_{D}$ and $M_{D M T}$ (constrained modulus obtained from SDMT) values with $G_{0}$ to assess the presence of microstructure as well as to identify the presence of unusual soils. The microstructure affects the behavior of tropical soils and $G_{0} / E_{D}$ and $G_{0} / M_{D M T}$ values of these soils are considerably higher than those observed in sedimentary soils. If soils have significant microstructure the methods and approaches to interpreted in situ tests may not always apply and site or geologic specific modifications may be required (Robertson, 2016; Berisavljevic \& Berisavljevic, 2019; Marchetti \& Monaco, 2019).

\section{MATERIALS AND METHODS}

\section{Study area}

The seismic tests were carried out in the experimental test site at the Universidade de São Paulo in São Carlos, Brazil. The soil profile is an example of typical tropical soil (ISSMFE, 1985). This profile is composed of a sandstone residual soil layer covered by a surficial unsaturated lateritic clayey sand layer (colluvial soil). A thick layer $(0.2$ to $0.5 \mathrm{~m})$ of pebbles separates the surficial layer from the residual soil. The groundwater level varies seasonally between 9 and $12 \mathrm{~m}$ below the ground surface. According to the Unified Soil Classification System (ASTM, 2011), both horizons can be classified as clayey sand (SC).

Several site characterization programs including standard penetration (SPT), cone penetration (CPT) and flat dilatometer (DMT) tests were carried out at this site. Sample pits were also excavated to retrieve undisturbed and disturbed soil blocks. Soil samples from these blocks were tested in laboratory for soil characterization and determination of mechanical properties and parameters. Figure 5 presents results of SPT, CPT and DMT tests. N-values from SPT tests and dilatometer modulus $\left(E_{D}\right)$ increase almost linearly with depth. The cone tip resistance $\left(q_{c}\right)$ 


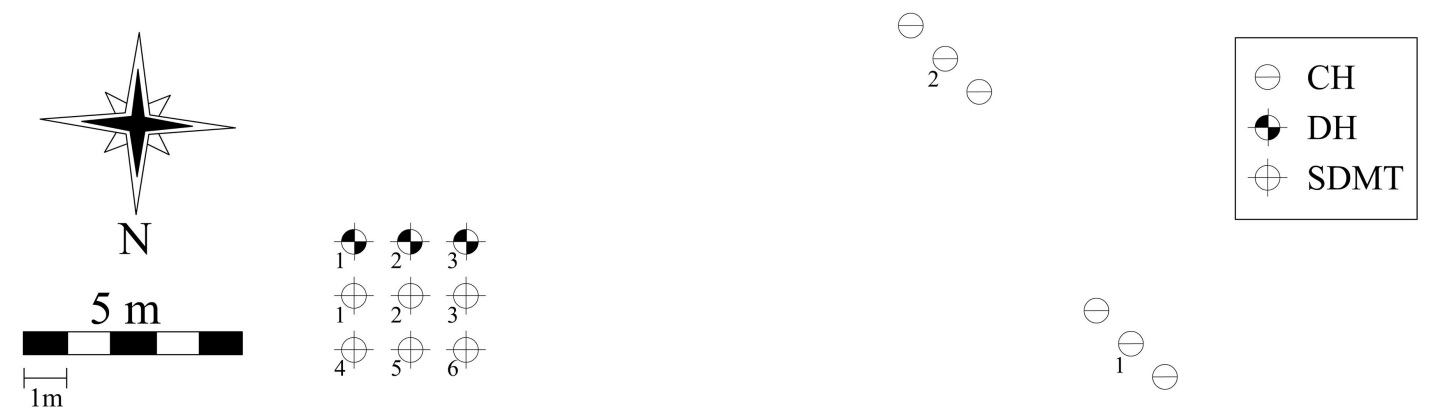

Figure 5 - Test locations of the crosshole (CH), downhole (DH) and SDMT carried out at the investigated site.

and the sleeve friction ( $f s$ ) tends to increase with depth leading to a friction ratio ( $\left.R f=f s / q_{c} * 100\right)$ between 4 and $8 \%$. The interpretation of MCT classification test (Nogami \& Villibor, 1981) data separated lateritic (LA') from non-lateritic (NA') soil behavior almost at the same depth $(6 \mathrm{~m})$.

\section{Seismic tests}

Two crosshole seismic tests ( $\mathrm{CH} 1$ and $\mathrm{CH} 2)$ were carried out in the site. Three boreholes spaced $3 \mathrm{~m}$ apart were installed for each test. The boreholes were drilled with a $150 \mathrm{~mm}$ diameter. The two receiver boreholes were cased with PVC pipes $75 \mathrm{~mm}$ diameter and the source borehole with PVC pipes $85 \mathrm{~mm}$ diameter. A grout mix that closely matches the formation density was used. The data were taken at every $1.0 \mathrm{~m}$ interval for the test $\mathrm{CH} 1$ and at every $0.5 \mathrm{~m}$ interval for the test $\mathrm{CH} 2$. The test procedure consisted of generating reverse polarity shear waves, first by impacting one end of a hammer source, and then by impacting the other end. Volts versus time traces, corresponding to each impact, were registered on an oscilloscope and recorded in a laptop computer for subsequent processing and analysis. Source and geophones are maintained at the same elevation for each measurement. Both crosshole tests were performed up to around $9 \mathrm{~m}$ depth due to limitation in the opening and preparing the boreholes below the groundwater level with the available equipment.

Three downhole tests were carried out using a seismic probe with three geophone compartments, spaced $0.5 \mathrm{~m}$ apart. This probe allows three records every test depth. The geophones are characterized by natural frequency of $28 \mathrm{~Hz}$, sensitivity of 35.4 $\mathrm{V} /(\mathrm{m} / \mathrm{s})$ and spurious frequency of $400 \mathrm{~Hz}$. The geophones were oriented in a uniaxial configuration, thus the axis of vibration was maintained parallel to the direction of the horizontal impacts of the hammer. This configuration allows the maximum response of the geophones (Campanella \& Howie, 2005). A steel bar placed on the ground surface was used as seismic source. It was positioned $0.3 \mathrm{~m}$ away from the borehole opening. The data were interpreted using the cross-correlation method and the true interval. The downhole tests were carried out up to $18 \mathrm{~m}$ depth.

Six SDMT (SDMT 1 to 6) were also carried out up to 20 $\mathrm{m}$ depth. The seismic source is the same used in the downhole test. It was oriented with its long axis parallel to the axis of the receivers, so that they can offer the highest sensitivity to the generated shear wave. The time delay from SDMT seismograms was determined using the cross-correlation algorithm. Figure 5 shows the location of the seismic tests.

\section{TEST DATA AND DISCUSSION}

\section{Seismic tests}

Figures 6,7 , and 8 show the seismograms acquired by crosshole, downhole and SDMT tests, respectively. Figure 6 presents the traces at $2 \mathrm{~m}$ depth, during the crosshole test $\mathrm{CH} 1$. The arrival time of S-wave was select using the reverse polarity. Figure 7 shows some traces obtained at $10 \mathrm{~m}$ depth, during the downhole test DH 1. It demonstrates that all three different geophones provided excellent quality recorders. It is noteworthy that, in general, it is possible to get recordings of similar quality for all the three geophones. Figure 8 shows the seismograms obtained by SDMT 1 at the $3.5,4.5$, and $5.5 \mathrm{~m}$ depth at the investigated site. It is a good practice to plot the seismograms side-by-side as recorded and re-phased according to the calculated delay.

Figure 9 shows the $V_{s}$ profiles measured by the different techniques. There is reasonable agreement among the $V_{s}$ profiles determined by the different techniques (Fig. 10). The shear wave velocities obtained by three techniques ranged from 194 to 370 $\mathrm{m} / \mathrm{s}$, with an average velocity of $295 \mathrm{~m} / \mathrm{s}$ with a $21 \mathrm{~m} / \mathrm{s}$ average standard deviation. The $V_{s}$ values measured from crosshole are little higher than those of downhole and SDMT. This behavior 

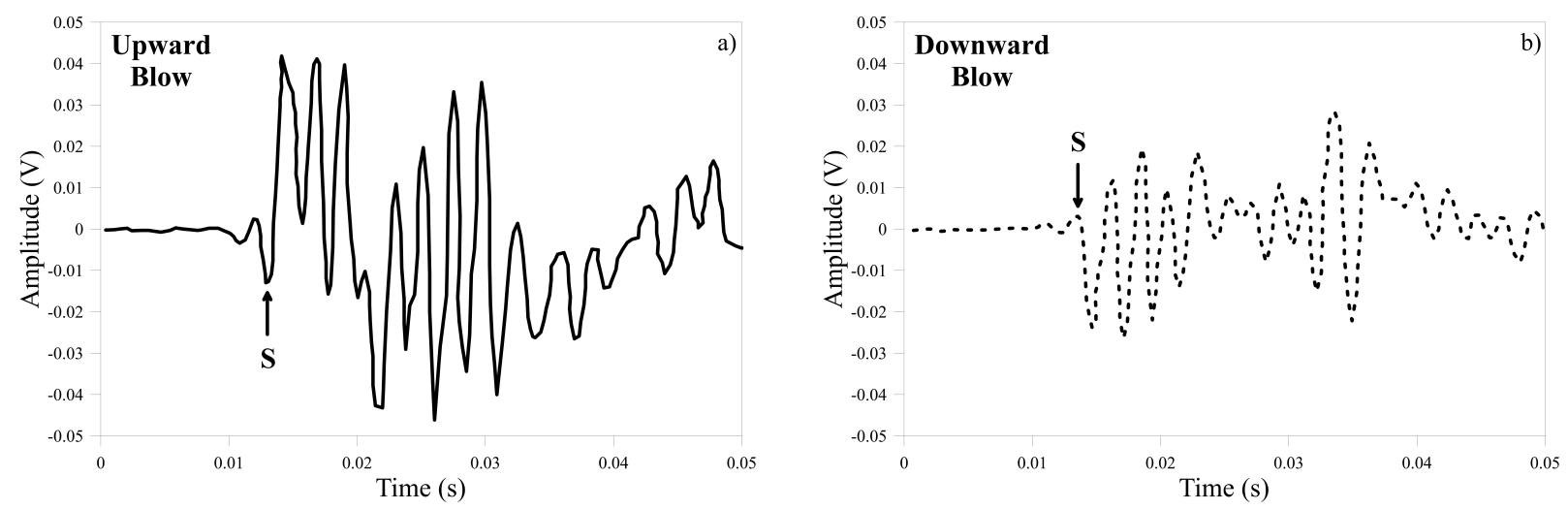

Figure 6 - Typical crosshole arrival traces (CH 2 at 2 m depth); a) Upward blow, b) Downward blow.

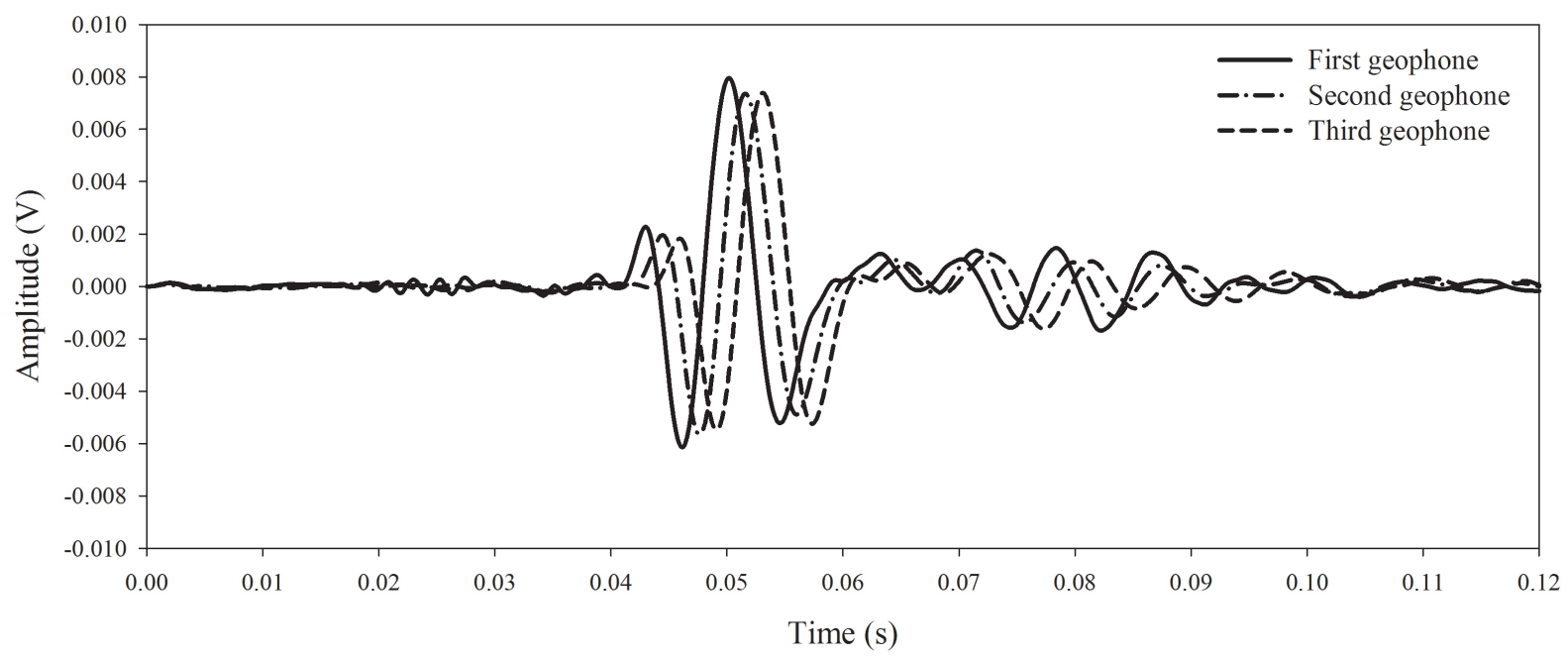

Figure 7 - Typical downhole shear wave arrival traces (DH 1 at $10 \mathrm{~m}$ depth).

can be attributed to the difference in the directions of propagation and polarization of shear waves induced by crosshole, downhole and SDMT (Butcher \& Powell, 1996; Fioravante et al., 1998; Viana da Fonseca et al., 2005). Cost-wise, the SDMT is clearly the choice for budgetary reasons. Furthermore, the SDMT provides additional readings including: corrected first reading $\left(p_{0}\right)$, corrected second reading $\left(p_{1}\right)$, and time derived from DMT decay dilatometer test $\left(T_{\text {flex }}\right)$ with depth. The collection of multiple measurements is beneficial towards a comprehensive site characterization program at any given site (Marchetti, 1980; Marchetti et al., 2001; Marchetti \& Monaco, 2018). However, the SDMT blade insertion in hard soils can be difficult precluding this test type.

Shear wave velocity are influenced by confining pressure and are expected to increase with the depth. The variation of $V_{s}$ with the total vertical stress $\left(\sigma_{v}\right)$ can be modeled using a power law expression presented in Equation 2, similar to the equation used by Hardin \& Drnevich (1972a, 1972b) and Valle-Molina \& Stokoe (2012).

$$
V_{s}=A_{s}\left(\frac{\sigma_{v}}{P_{a}}\right)^{n_{s}}
$$

In this expression, As is the shear wave velocity for 100 $\mathrm{kPa}$ of vertical stress, $n_{s}$ is a dimensionless exponent of vertical pressure normalized by atmospheric pressure $\left(P_{a}=100 \mathrm{kPa}\right)$.

Figure 11 shows the measured $V_{s}$ and the fitting curves considering Equation 2. The soil unit weight was equal to 14 $\mathrm{kN} / \mathrm{m}^{3}$ up to $8 \mathrm{~m}$ depth and to $16 \mathrm{kN} / \mathrm{m}^{3}$ from then on. From best fitting analysis As is $288 \mathrm{~m} / \mathrm{s}$ and $n_{s}$ is 0.15 . S-wave velocity increased with the vertical stress with fitted $n_{s}$ value of the same 


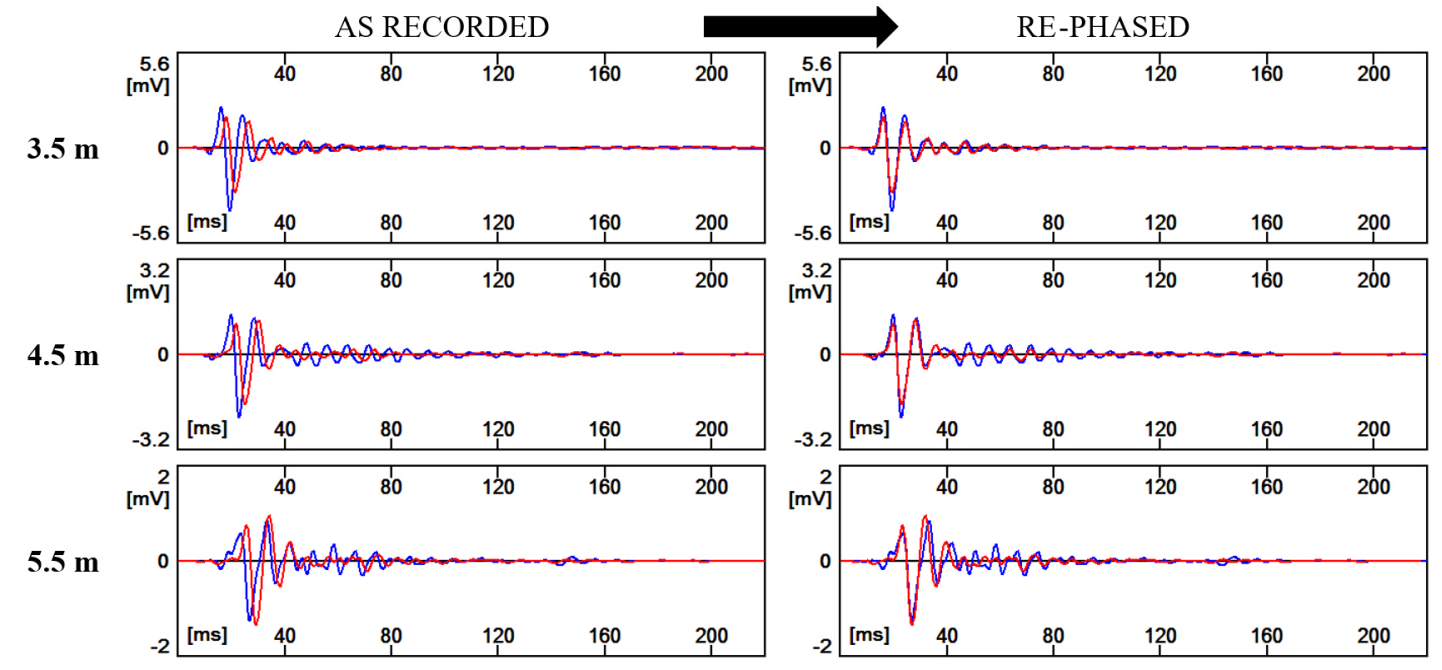

Figure 8 - Example of seismograms obtained by SDMT 1 at the 3.5, 4.5, and $5.5 \mathrm{~m}$ depth.
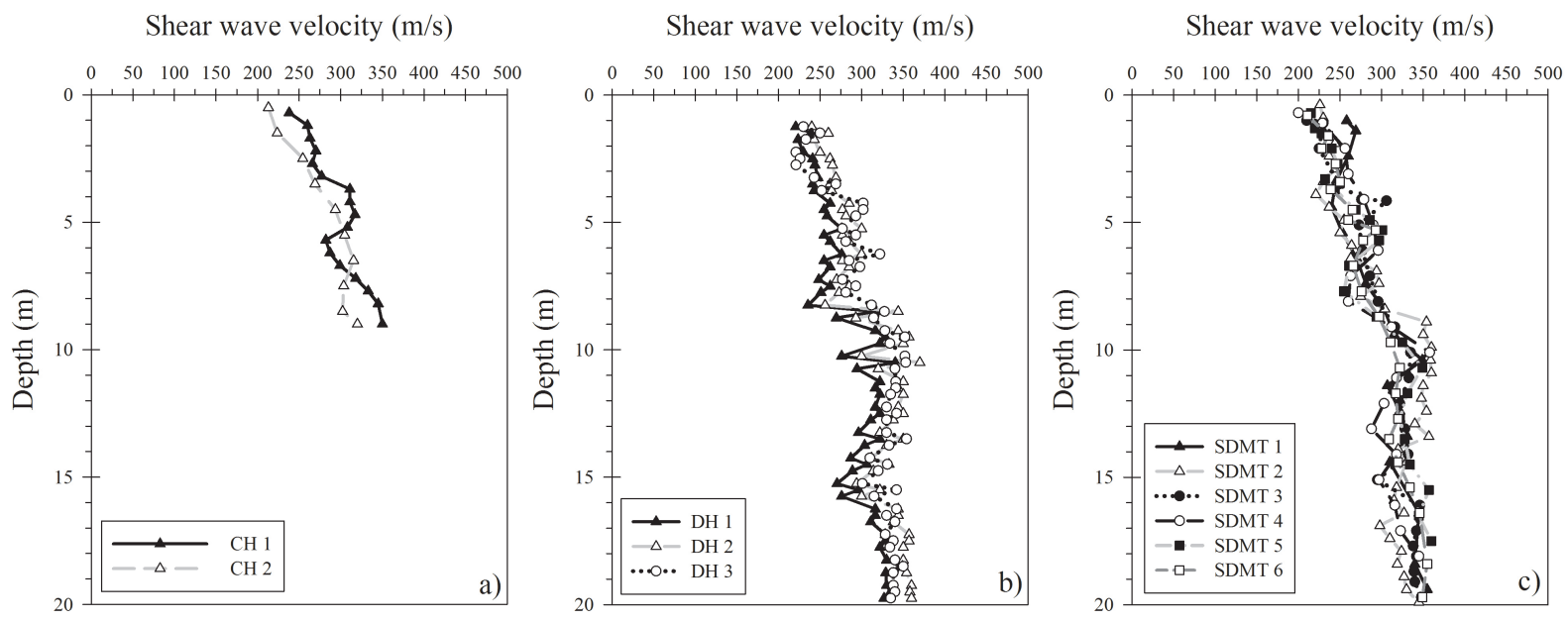

Figure 9 - Comparison among $V_{S}$ measured by a) crosshole, b) downhole and c) SDMT test for study area.

magnitude of those measured by Valle-Molina \& Stokoe (2012) in sands.

The scatter in the crosshole, downhole and SDMT data (Figs. 9 and 10) combined with field observations, suggests that the study area can be divided into two layers, instead of considering it as a uniform media. In fact, it is possible to notice an upper stratum that reaches 8 meters depth. In the upper stratum $V_{s}$ ranged from 194 to $305 \mathrm{~m} / \mathrm{s}$, with an average velocity of 259 $\mathrm{m} / \mathrm{s}$. In the lower stratum (between 8 and $18 \mathrm{~m}$ depth) $V_{s}$ ranged from 250 to $370 \mathrm{~m} / \mathrm{s}$, with an average velocity of $325 \mathrm{~m} / \mathrm{s}$. Table 1 presents the statistics for these data. The mean values of $V_{s}$ increase from the upper to the lower stratum, which was expected, considering the increase in confining stress and the denser and stiffer state of the soil. The larger dispersion in upper stratum can be explained to be a consequence of the unsaturated condition (Cho \& Santamarina, 2001; Gui \& Yu, 2008; Nyunt et al., 2011; Dong \& Lu, 2016) as well as the inherent variability (Gidigasu, 1976; ISSMFE, 1985; Giacheti et al., 2006b; Gutierrez et al., 2009) typical in lateritic tropical soils.

\section{The $G_{0}, G_{0} / E_{D}$ and $G_{0} / M_{D M T}$ ratio}

The $G_{0}$ was calculated by Equation 1. Soil unit weight $(\gamma)$ was determined from undisturbed soil samples collected in sample pits excavated at the site (ABNT, 2016). The $G_{0}$ range between 75 to $233 \mathrm{MPa}$, with an average of $151 \mathrm{MPa}$ with a $19 \mathrm{MPa}$ average standard deviation. 


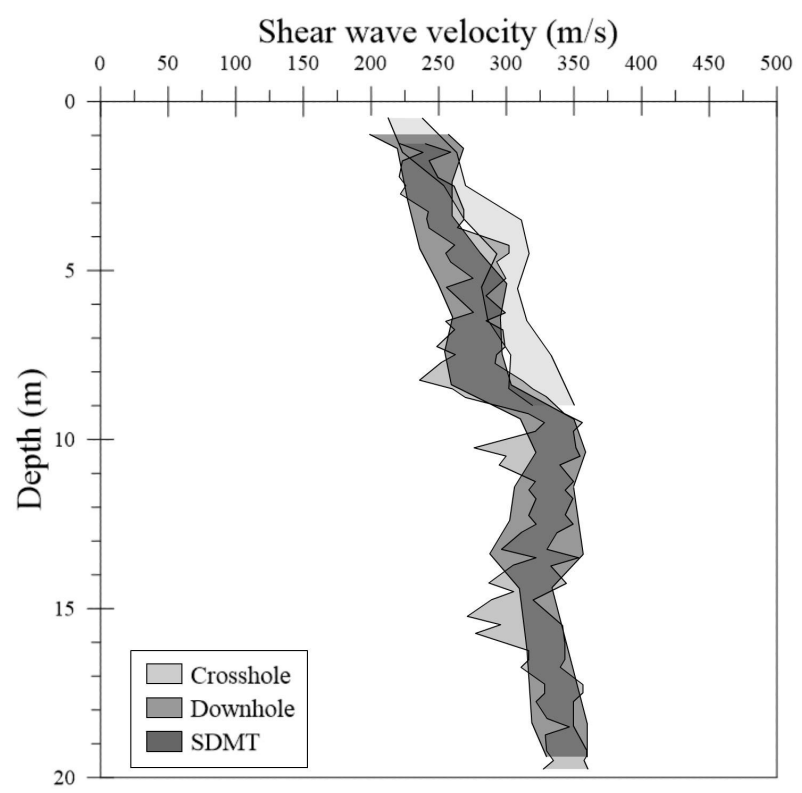

Figure $\mathbf{1 0}$ - Shear wave velocity measured in the crosshole, downhole and SDMT tests in the study area.

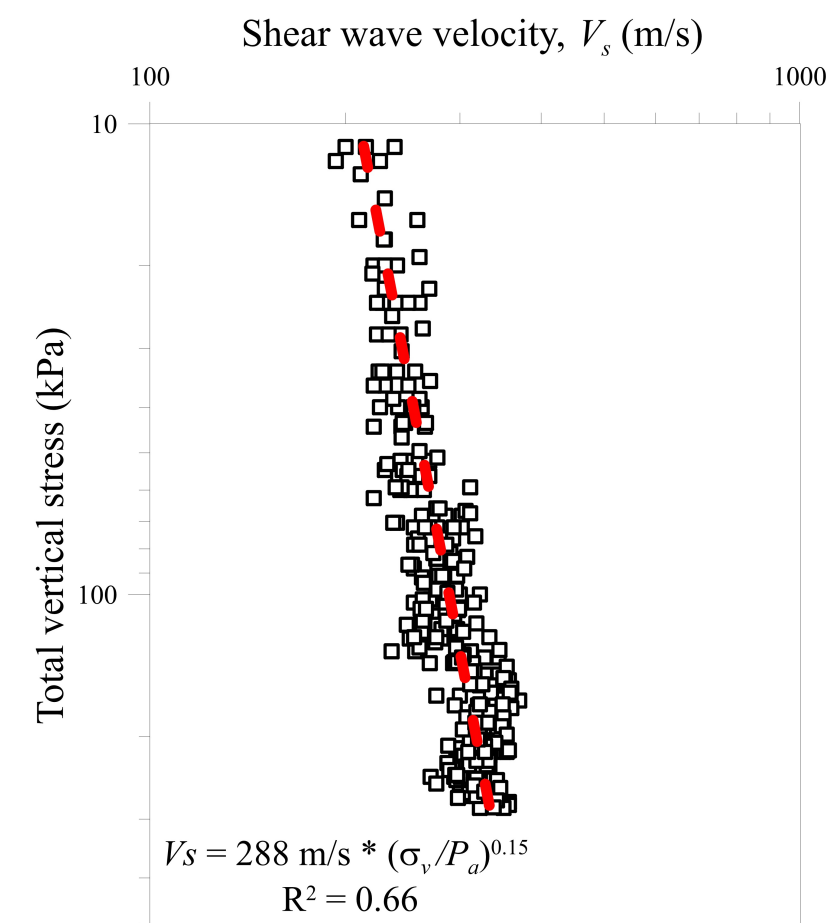

Figure 11 - Variation of shear wave velocity with total vertical stress for the study area. 
Table 1 - Statistic of the crosshole, downhole and SDMT tests results.

\begin{tabular}{|c|c|c|c|c|c|c|c|}
\hline & Stratum & Observations & $\begin{array}{c}\text { Minimum } \\
(\mathrm{m} / \mathrm{s})\end{array}$ & $\begin{array}{c}\text { Maximum } \\
(\mathrm{m} / \mathrm{s})\end{array}$ & $\begin{array}{c}\text { Average } \\
(\mathrm{m} / \mathrm{s})\end{array}$ & $\begin{array}{c}\text { Standard deviation } \\
(\mathrm{m} / \mathrm{s})\end{array}$ & $\begin{array}{c}\text { Coefficient } \\
\text { of variation }\end{array}$ \\
\hline \multirow{2}{*}{$V_{s}$} & Upper & 152 & 194 & 305 & 259 & 52 & 0.200 \\
\cline { 2 - 8 } & Lower & 145 & 250 & 370 & 325 & 40 & 0.123 \\
\hline
\end{tabular}
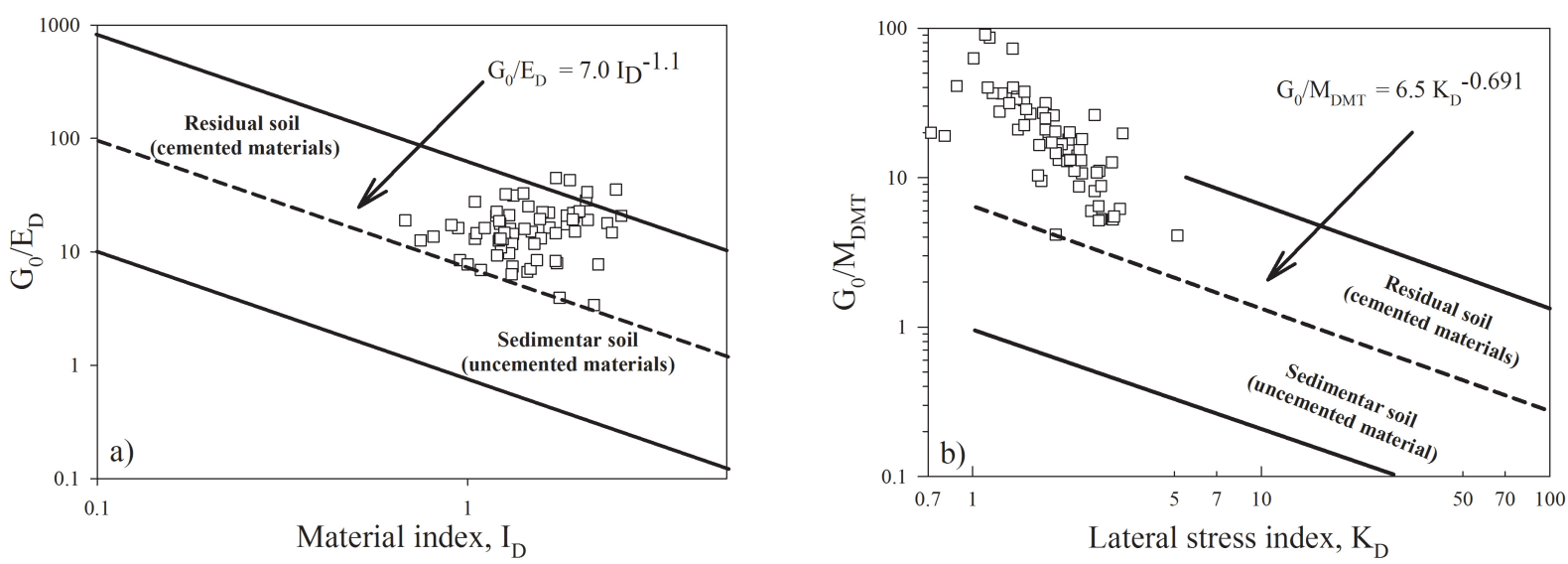

Figure 12 - SDMT data plotted on $G_{0} / E_{D}$ vs $I_{D}$ chart (a) and $G_{0} / M_{D M T}$ vs $K_{D}$ chart (b) (adapted from Cruz et al., 2012).

Figures $12 \mathrm{a}$ and $12 \mathrm{~b}$ show the $G_{0} / E_{D}$ vs $I_{D}$ and $G_{0} / M_{D M T}$ vs $K_{D}$ charts, respectively, suggested based on the findings from Cruz et al. (2012). $I_{D}, K_{D}, E_{D}$ and $M_{D M T}$ were calculated according to Marchetti (1980) and Marchetti et al. (2001).

In both charts the plotted SDMT data from six tests are above the equation line which separates the sedimentary to the residual soil. It indicates that the bonded structure of studied tropical soils produces $G_{0} / E_{D}$ as well as $G_{0} / M_{D M T}$ that are systematically higher than those measured in sedimentary soils. In soil where there is significant microstructure like the tropical soils the classification of soil type and geotechnical properties estimative becomes less reliable and some judgment is required (Marchetti \& Monaco, 2018; Robertson, 2016).

\section{CONCLUSION}

The crosshole, downhole and seismic dilatometer (SDMT) tests allow the determination of $V_{s}$, and corresponding calculation of $G_{0}$ for geotechnical engineering applications mainly in soil dynamic analysis.

$V_{s}$ and $G_{0}$ profiles determined by crosshole, downhole and SDMT show good agreement at the study area. Consequently, any techniques (crosshole, downhole and SDMT) can be used to determined shear wave velocity in this site. The shear wave velocity profile suggests the presence of two strata in the study area, which are in agreement with soil profile description.

Both charts from Cruz et al. (2012) indicate the presence of cemented structures in the site. The bonded structure of tropical sandy soils produces $G_{0} / E_{D}$ as well as $G_{0} / M_{D M T}$ which are systematically higher than those measured in sedimentary soils. If the soil has a significant microstructure the classification charts and most existing empirical correlations may not always be applied and site or geologic specific modifications are required.

The crosshole is the most reliable method to determine in situ $V_{s}$ profile. However, this technique is less used due to its high cost. The seismic dilatometer (SDMT) is particularly well-suited, efficient and economical tool for routine site characterization. The test data allows a direct quantification of soil properties such as shear strength, deformability and permeability and the $G_{0}$ profile is determined directly for soil dynamic analyses.

\section{ACKNOWLEDGMENTS}

The authors are grateful to the São Paulo Research Foundation - FAPESP (Grant \# 2015/16270-0) and the National Council 
for Scientific and Technological Development (CNPq) (Grant \# 310867/2012-6 and 446424/2014-5) for their financial support.

\section{REFERENCES}

ABNT. 2016. NBR 9604. Well opening and soil profile inspection trench, with removal of disturbed and undisturbed soil samples — Procedure. Rio de Janeiro, Brazil: Associação Brasileira de Normas Técnicas - ABNT, 9 pp. [in Portuguese].

ASHFORD SA \& SITAR N. 2002. Simplified method for evaluating seismic stability of steep slopes. J Geotech Geoenviron Eng, 128(2): 119-128. doi: 10.1061/(ASCE)1090-0241(2002)128:2(119).

ASTM. 2007. Standard, D4428-07. Standard test methods for Crosshole seismic testing. West Conshohocken, PA, USA: ASTM International. 2007. $11 \mathrm{pp}$.

ASTM. 2008. Standard, D7400-08. Standard test methods for Downhole seismic testing. West Conshohocken, PA, USA: ASTM International. 2008. $11 \mathrm{pp}$.

ASTM. 2011. D2487-11. Standard practice for classification of soils for engineering purposes (Unified Soil Classification System). West Conshohocken, PA, USA: ASTM International. 2011, 12 pp.

BALIGH MM \& SCOTT RF. 1975. Quasi Static Deep Penetration in Clays. ASCE J Geotech Eng, 101(GT11): 1119-1133.

BANG ES \& KIM DS. 2007. Evaluation of shear wave velocity profile using SPT based uphole method. Soil Dyn Earthq Eng, 27(8): 741-758. doi: 10.1016/j.soildyn.2006.12.004.

BERISAVLJEVIC D \& BERISAVLJEVIC Z. 2019. Determination of the presence of microstructure in a soil using a seismic dilatometer. Bulletin of Engineering Geology and the Environment, 78(3): 1709-1725. doi: 10.1007/s10064-018-1234-5.

BURLAND JB, LONGWORTH TI \& MOORE JFA. 1977. Study of ground and progressive failure caused by a deep excavation in Oxford Clay. Géotechnique, 27(4): 557-591.

BUTCHER AP \& POWELL JJM. 1996. Practical considerations for field geophysical techniques used to assess ground stiffness. In: Advances in Site Investigation Practice. Thomas Telford, London, p. 701-714.

CAMPANELLA RG \& HOWIE JA. 2005. Guidelines for the use, interpretation and application of seismic piezocone test data. Geotechnical Research Group Department of Civil Engineering. University of British Columbia, Vancouver. 305 pp.

CAMPANELLA RG \& STEWART WP. 1992. Seismic cone analysis using digital signal processing for dynamic site characterization. Can Geotech J, 29(3): 477-486. doi: 10.1139/t92-052.

CHO GC \& SANTAMARINA JC. 2001. Unsaturated Particulate Materials —Particle-Level Studies. J Geotech Geoenviron Eng, 127(1): 84-96. doi: 10.1061/(ASCE)1090-0241(2001)127:1(84).
CRUZ N, RODRIGUES C \& FONSECA AV. 2012. Detecting the presence of cementation structures in soils, based in DMT interpreted charts. In: 4th International Conference on Site Characterization (ISC4). Porto de Galinhas, Brazil. v.1. p. 1723-1728.

DONG Y \& LU N. 2016. Dependencies of Shear Wave Velocity and Shear Modulus of Soil on Saturation. J Eng Mech, 142(11): 04016083. doi: 10.1061/(ASCE)EM.1943-7889.0001147.

FIORAVANTE V, JAMIOOLKOWSKI M, LO PRESTI DCF, MANFREDINI G \& PEDRONI S. 1998. Assessment of the coefficient of Earth pressure at rest from shear wave velocity measurements. Géotechnique. 48(5): 657-666.

GIACHETI HL, DE MIO G \& PEIXOTO ASP. 2006a. Cross-hole and seismic CPT tests in a tropical soil site. In: DE GROOT DJ, DEJONG JT, FROST D \& BAISE LG (Eds.). Proceedings of GeoCongress 2006: Geotechnical Engineering in the Information Technology Age. American Society of Civil Engineers (ASCE). Atlanta, Georgia. doi: 10.1061/40803(187)92.

GIACHETI HL, DE MIO G, DOURADO JC \& MALAGUTTI W. 2006b. Comparing down-hole and cross-hole seismic tests results on the Unesp Bauru research site. In: 13th Brazilian Congress of Soil Mechanics and Geotechnical Engineering. Curitiba, Brazil. v. 2, p. 669-674. [in Portuguese].

GIDIGASU MD. 1976. Laterite Soil Engineering: Pedogenesis and Engineering Principles. Developments in Geotechnical Engineering, Elsevier, N.Y., $554 \mathrm{pp}$.

GUI M-W \& YU C-M. 2008. Rate of strength increase of unsaturated lateritic soil. Can Geotech J, 45(9): 1335-1343. doi: 10.1139/T08-065.

GUTIERREZ NHM, NÓBREGA MT \& VILAR OM. 2009. Influence of the microstructure in the collapse of a residual clayey tropical soil. Bull Eng Geol Environ, 68(1): 107-116. doi: 10.1007/s10064-008-0180-z.

HARDIN BO \& DRNEVICH VP. 1972a. Shear modulus and damping in soils: measurement and parameter effects. J Soil Mech Found Eng Div, 98(SM6): 603-624.

HARDIN BO \& DRNEVICH VP. 1972b. Shear modulus and damping in soils: design equations and curves. J Soil Mech Found Eng Div, 98(SM7): 667-692.

HEPTON P. 1988. Shear wave velocity measurements during penetration testing. In: Penetration Testing in the UK. Birmingham. ICE, 275-278.

HUNTER JA, BENJUMEA B, HARRIS JB, MILLER RD, PULLAN SE, BURNS RA \& GO0D RL. 2002. Surface and downhole shear wave seismic methods for thick soil site investigations. Soil Dyn Earthq Eng, 22(9-12): 931-941. doi: 10.1016/S0267-7261(02)00117-3.

ISSMFE. 1985. Committee on Tropical Soils of ISSMFE. 1985. Peculiarities of geotechnical behavior of tropical lateritic and saprolitic soils: progress report (1982-1985). São Paulo, SP, Brazil. Ed. Edile. 
KARL L, HAEGEMAN W \& DEGRANDE G. 2006. Determination of the material damping ratio and the shear wave velocity with seismic cone Penetration test. Soil Dyn Earthq Eng, 26(12): 1111-1026. doi: 10.1016/j.soildyn.2006.03.001.

KIM DS \& PARK HC. 1999. Evaluation of ground densification using SASW method and resonant column tests. Can Geotech J, 36(2): 291-299. doi: 10.1139/t98-103.

MARCHETTI S. 1980. In Situ Tests by Flat Dilatometer. ASCE J Geotech Eng, 106(GT3): 299-321.

MARCHETTI S \& MONACO P. 2018. Recent Improvements in the Use, Interpretation, and Applications of DMT and SDMT in Practice. ASTM, Geotech Testing J, 41(5): 837-850. doi: 10.1520/GTJ20170386.

MARCHETTI S \& PANONE C. 1981. Distortions Induced in Sands by Probes of Different Shapes. Rivista Italiana di Geotechnica, 15(1): 50-54. [in Italian].

MARCHETTI S, MONACO P, TOTANI G \& CALABRESE M. 2001. The Flat Dilatometer Test (DMT) in Soil Investigations. TC16 Report. In: IN SITU 2001, International Conference on In situ Measurement of Soil Properties. Indonesia, $41 \mathrm{pp}$.

MARCHETTI S, MONACO P, TOTANI G \& MARCHETTI D. 2008. In Situ Tests by Seismic Dilatometer (SDMT). In: Symposium Honoring Dr. John H. Schmertmann for His Contributions to Civil Engineering at Research to Practice in Geotechnical Engineering Congress. New Orleans, Louisiana, United States. p. 292-311.

MARTIN GK \& MAYNE PW. 1997. Seismic Flat Dilatometer Tests in Connecticut Valley Varved Clay. ASTM Geotech Testing J, 20(3): 357-361.

MARTIN GK \& MAYNE PW. 1998. Seismic flat dilatometer in Piedmont residual soils. In: 1st International Conference on Site Characterization ISC'98. Atlanta, vol. 2, p. 837-843.

MAYNE PW, SCHNEIDER JA \& MARTIN GK. 1999. Small- and large-strain soil properties from seismic flat dilatometer tests. In: 2nd International Symposium on Pre-Failure Deformation Characteristics of Geomaterials. Turin, Italy. v.1, p. 419-427.

NOGAMI JS \& VILLIBOR DF. 1981. A new soil classification for highway purposes. In: Symposium on Tropical Soils in Engineering. Rio de Janeiro, Brazil: COPPE/UFRJ-ABMS. v. 1, p. 30-41. [in Portuguese]

NYUNT TT, LEONG EC \& RAHARDJO H. 2011. Strength and Small-Strain Stiffness Characteristics of Unsaturated Sand. Geotech Test J, 34(5): 551-561. doi: 10.1520/GTJ103589.
ROBERTSON PK. 2016. Cone Penetration Test (CPT)-Based Soil Behaviour Type (SBT) Classification System - An Update. Can Geotech J, 53(12): 1910-1927. doi: 10.1139/cgj-2016-0044.

ROCHA BP. 2018. Caracterização Geotécnica de Solos Tropicais Não Saturados por meio de Ensaios de campo. Ph.D. Thesis - Programa de Pós-graduação em Geotecnia. Departamento de Geotecnia, Universidade de São Paulo, Brazil. 2018. 240 pp.

STOKOE KH, JOH SH \& WOODS RD. 2004. Some contributions of in situ geophysical measurements to solving geotechnical engineering problems. In: 2nd International Conference on Site Characterization. Porto, Portugal, p. 97-132

SULLY JP \& CAMPANELLA RG. 1995. Evaluation of in-situ anisotropy from crosshole and a downhole shear wave velocity measurements. Géotechnique, 45(2): 267-282. doi: 10.1680/geot.1995.45.2.267.

UBC. 1997. Uniform Building Code (International Building Code), International Code Council. International Conference of Building Officials. 1997.

VALLE-MOLINA C \& STOKOE II KH. 2012. Seismic measurements in sand specimens with varying degrees of saturation using piezoelectric transducers. Can Geotech J, 49(6): 671-685. doi: 10.1139/t2012-033.

VAUGHAN PR, MACCARINI M \& MOKHTAR SM. 1988. Indexing the engineering properties of residual soil. Quarterly Journal of Engineering Geology, 21(1): 69- 84.

VIANA DA FONSECA A, CARVALHO J \& FERREIRA C. 2005. The use of shear wave velocities determined in Down-Hole $\left(V_{s}^{v h}\right)$ and Cross-Hole $\left(V_{s}^{h v}\right)$ tests for the evaluation of $\mathrm{K}_{0}$ in soils. ABMS, Brazil. Solos $\mathrm{e}$ Rochas, 28(3): 271-281.

VUCETIC M \& DOBRY R. 1991. Effect of Soil Plasticity on Cyclic Response. ASCE J Geotech Eng, 117: 89-107.

WANG Z, ZHANG N, CAI G, LI Q \& WANG J. 2018. Field Investigation of Maximum Dynamic Shear Modulus of Clay Deposit using Seismic Piezocone. Int J Civ Eng, 17(6): 699-708. doi: 10.1007/s40999-018-0306-Z.

WOODS RD. 1978. Measurement of dynamic soil properties - State of the Art. In: ASCE Speciality Conference on Earthquake Engineering and Soil Dynamics. Pasadena, California. v.1, p. 91-178. 